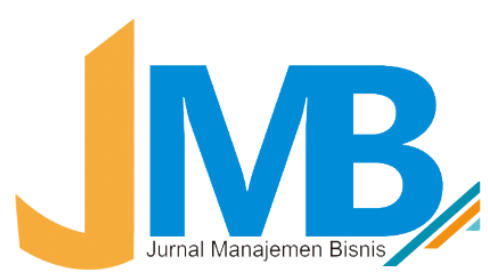

\title{
CAUSALITY MODEL OF CONSUMER PURCHASE INTENTION ON ENVIRONMENTALLY FRIENDLY PACKAGING BEVERAGE PRODUCTS
}

\author{
Muhammad Zulfiqar Mahmud ${ }^{1}$; Widayat $^{2}$; Rahmad Wijaya $^{3}$ \\ ${ }^{1}$ Graduate Program of University of Muhammadiyah Malang \\ 23 Faculty of Economics and Business University of \\ Muhammadiyah Malang \\ ${ }^{2}$ Corresponding author: widayat@umm.ac.id
}

Received:02-10-2020 | Revision: 07-10-2020 | Accepted:28-10-2020

To cite this document:

Muhammad Zulfiqar Mahmud; Widayat; Rahmad Wijaya, (2020) Causality Model of Consumer Purchase Intention on Environmentally Friendly Packaging Beverage Products, Manajemen Bisnis, Vol.10,No.02, pp.36-50.

https://doi: 10.22219/jmb.v10i2.14791

\begin{abstract}
This study aims to construct a correlational model for the determinant of consumer purchase intention on environmentally friendly packaging beverage products by examining the product image and company reputation as mediators in the association of green perceived value on consumer purchase intention with the ex-post facto quantitative approach. The target population is the community in Malang City, East

Java who is aware of the existence of cardboard packaging beverage products and intends to purchase the products. Data were collected by employing a questionnaire distributed online. 300 respondents were selected by convenience sampling. The collected data were analyzed using Structural Equation Modeling (SEM) by utilizing AMOS software. The final model was obtained with an adequate Goodness of Fit value.

The structural model that has been successfully constructed shows that green perceived value has no significant effect on purchase intention. Besides, the product image and company reputation play a role in mediating the impact of Green Perceived Value on Purchase Intention.
\end{abstract}

Keywords: Perceived Value, Product Image, Reputation, Purchase Intention, Green Product

\section{INTRODUCTION}

Although Green Marketing is not a new concept, it is still appealing and relevant to be reviewed today. One reason why this review is interesting is that the environmental issues on this earth are still unsolved. The term green marketing is a strategy employed by companies to fulfill consumers' desires who are aware of the environment. The main objective is to protect the environment from various kinds of environmental issues indirectly. It is also a form of corporate responsibility to the environment due to the impact of the production and distribution process. This strategy is expected to market the products in several criteria, such as environmentally friendly and safe products that focus on the earth, nature, and even the ozone layer (Singhal \& Malik, 2018; Widyastuti \& Santoso, 2016).

Studies on green marketing can be observed from the consumer side. A concept relevant to green marketing from a consumer's perspective and the value perceived 
directly by consumers is known as green perceived value. Green perceived value is an overall consumer assessment of the benefits of a product or service between what is seen and what the company provides based on the consumer's environmental desires, sustainable expectations, and the need for a better environment (Chen \& Chang, 2012). Companies committed to the better environment by applying green marketing producing environmentally friendly products. However, the success of the company's green marketing strategy will not be realized without good reception from consumers. Accordingly, the interesting issue associated with this strategy from the consumer side is whether consumers are also willing to purchase environmentally friendly products or intend to buy products packaged in an environmentally friendly manner. As a result, investigating the green perceived value of consumers also needs to be conducted.

Consumer behavior, specifically the behavior and intention to purchase environmentally friendly products, is an interesting object to be studied amid the global community's concern for environmental pollution. Theoretically and empirically, there are various factors to be considered by consumers in deciding to buy a product or service. One of the considerations is related to environmental factors. Empirical evidence shows that consumers are aware of the environmental problems even though their awareness is not in line with environmentally friendly behavior. The consumers are yet ready to direct their purchase intentions to environmentally friendly products (do Paço \& Raposo, 2009).

Moreover, the consumers' awareness of social and environmental issues has increased significantly. Consumers are willing to spend more to buy products that are social issues and environmentally friendly. This shows that consumers are increasingly involved in environmental issues (Nielsen Global Corporate Sustainability Report, 2015). According to data from Tetra Pak Company (www.tetrapak.com, 2018), around $80 \%$ of the community tended to buy products with environmentally friendly packaging. On the other hand, approximately 40\% stated that eco-friendly logos (eco-label) could help them understand the environmental impact of packaging and make them more attractive. Meanwhile, previous research discovered that green perceived value, which was the conclusion of the green marketing strategy that companies offered to consumers, had a positive effect on purchase intention by paying attention to consumer reactions and perceptions. Another consumer perspective considered that green perceived value in consumers significantly impacted consumer purchase intention by paying attention to social responsibility, brand image, and company reputation (Ko, Hwang, \& Kim, 2013). This shows that green perceived value affects consumer intentions to buy environmentally friendly products.

On the other hand, several studies revealed that green perceived value did not affect consumer purchase intention. The company's green marketing strategy to create green perceived value for consumers so that they intended to buy the product turned out to be insignificant due to the greenwashing issue. One of the green marketing communication patterns, namely normative interpersonal influence, indicated that this communication pattern's green perceived value was not significant to consumer purchase intention (Chang, 2015). In other words, it can be concluded that the relationship between green perceived value and consumer purchase intention shows inconsistency. Consequently, it is crucial to determine the mediating variable that will connect the green perceived value to consumer purchase intention logically and coherently. In this research, the product image and reputation variables are expected to 
be mediators in the relationship between green perceived value and consumer purchase intention. Several studies claimed that green perceived value affected consumer purchase intention, while others said otherwise. For example, Chang (2015) stated that green perceived value had no significant effect on purchase intention.

Green marketing strategies are applied to various companies, especially in Indonesia. One company that produces environmentally friendly packaging is Tetra Pak. Tetra Pak is a company engaged in the processing and packaging of food and beverages with safe, innovative, and environmentally friendly packaging. The type of packaging produced is made from cardboard. The form of corporate awareness on the environment is manifested in packaging by implementing the $3 \mathrm{R}$ (Reuse, Reduce, \& Recycle) system. The packaged beverage product is labeled with a $3 \mathrm{R}$ symbol and a slogan. One of the slogans reads, "Anda ikut melestarikan hutan di dunia dengan memilih produk dalam kemasan karton ini (You are helping to preserve the world's forests by choosing products in this cardboard packaging)." However, a relevant and interesting issue is whether consumers intend to buy environmentally friendly packaged products. Departing from the above explanation, this article is designed to test a model that links the green perceived value, either indirectly or directly, with purchase intention through mediating variables of the product image and company reputation.

\section{LITERATURE REVIEW}

Purchasing Intention

According to the Theory of Planned Behavior, the intention is a predictor of behavior. Ajzen (1985) claimed that there are three main factors in this theory that shape the purchase intention, namely attitude, subjective norm, and perceived behavioral control. In this concept, the purpose is a variable that precedes a person's behavior. Regarding the purchase intentions, Assael (1998) and Widayat (2018a) argued that purchase intention is a behavior that appears in response to an object indicating a consumer's desire to make a purchase. Purchase intention can also be defined as a decision to act on a product that consumers want (X. Wang \& Yang, 2008). Furthermore, purchase intention is correlated with demographic factors such as age, gender, profession, and education (Rezvani et al., 2012). Meanwhile, environmentally friendly purchase intention is conceptualized as a probability and willingness of a person to like products with environmentally friendly features compared to other products in consideration of purchase (Rashid, 2009). Purchase intention can be measured by three indicators, namely products/services relevant to future focus, consideration as the first choice for buying product /services, and product focus in the next few years (Keh \& Xie, 2009). Other indicators of purchase intention are an environmental concern, which is the primary consideration in buying certain products, the desire to purchase certain products in the future, environmentally friendly features which are common reasons for purchasing specific products, trust in products, certainty to choose, and certainty of buying products. (Chen \& Chang, 2012).

\section{Green Perceived Value}

One of the elements of green marketing that consumers can feel and assess is green perceived value. Green perceived value is one of the essential things for environmentally friendly product users. Green perceived value can increase awareness of social values. If a product performs poorly in matters related to the social environment, negative incidents such as dissatisfaction may occur (Doszhanov \& Ahmad, 2015). Green perceived value is defined as a consumer's overall assessment of a 
product's net benefits or service between what is received and what is given based upon consumer desires, sustainable expectations, and environmentally friendly needs (Chen \& Chang, 2012). Besides, it is defined as the net gain from an overall consumer assessment by evaluating a product and service. The greater the consumer's trust in the perceived benefits of a product and the smaller the perceived risk from purchasing a product, the greater the chance that the consumer will purchase the product (S. A. Dewi \& Rastini, 2016). green perceived value indicators include the products provide excellent value to consumers, the product performance meets consumer expectations, consumers purchase products that pay more attention to the environment than other products, consumers purchase the products because they are environmentally friendly, and consumers purchase the products because the benefits (environment) are more than the other products (Chen \& Chang, 2012).

Image of Product

Image of Product is a description of the product from the consumers' perspective based on their knowledge, responses, and experiences towards the product ( $\mathrm{Li}$, Wang, \& Cai, 2011). Furthermore, Alma (2007) defined a product image as a person's perception of a set of attributes in a tangible or intangible product. Moreover, a product image is a set of associations perceived by consumers towards a positively assessed product in the eyes of the public, both those who have become real consumers and targeted consumers (Mandagie, 2018). In general, the perception of a product can be identified from the quality of the product. According to the American Society for Quality Control, product quality includes all the characteristics inherent in a product or service that demonstrate its ability to implicitly satisfy the consumer needs. Four product image indicators are perceived quality, product performance expectations, intention to buy the products, and the price to be paid (Jessie Chen-Yu \& Kincade, 2001). The other five product image indicators are high quality, easily recognized, high manufacture, reliable/trustworthy, and well designed (C. L. Wang, Li, Barnes, \& Ahn, 2012).

Company Reputation

The company's reputation is the consumer's perception of the company's ability to provide the best service, or an assessment of past conditions and future prospects regarding the quality of the company or product (Salim, 2019). The research result indicated that companies with favorable reputations benefit from building trust and identification among customers, which can positively influence customer commitment (Keh \& Xie, 2009). A company's reputation can be measured by a superior company, a successful company, and a well-established company (Keh \& Xie, 2009). Further, Ko et al. (2013) suggested two indicators of company reputation: the overall image of a company with a traditional reputation and global competitiveness. Other indicators in building a company's reputation include financial capability, product and service quality, focus on customers, human resource excellence and sensitivity, reliability, innovation, environmental responsibility, social responsibility, and enforcement of good corporate governance (GCG) (Pratiwi, 2013).

From the explanation of the concept above, the framework for the relation of variables can be described in Figure 2 and the formulation of the hypotheses. 


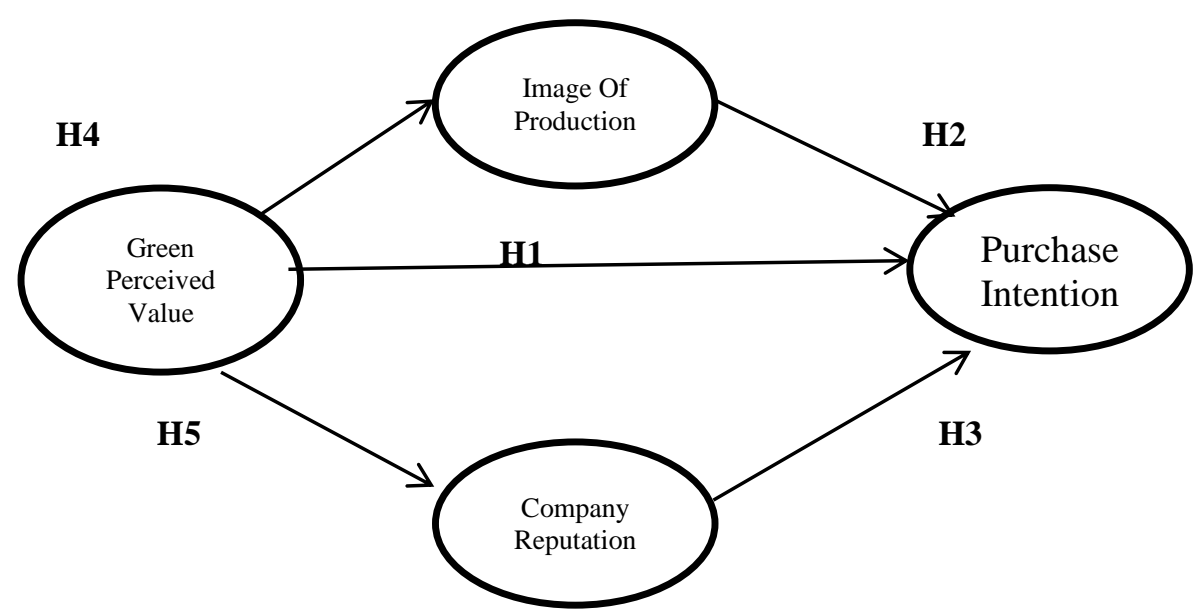

Figure 2 Framework

\section{Green Perceived Value towards Purchase Intention}

Green perceived value is interpreted as the consumers' overall appraisement of the net advantages of a good or service between what is accepted and what is delivered based on the consumer's environmental desires, sustainable expectations, and environmentally friendly needs. Several studies showed that green perceived value, which was the conclusion of the green marketing strategy that companies offered to consumers, significantly affected purchase intention by paying attention to consumer reactions and perceptions (Fonseca, 2015). Another consumer perspective assumed that green perceived value in consumers significantly affected the consumer purchase intention by considering the social responsibility, brand image, and company reputation (Ko et al., 2013). Other research also indicated that green perceived value as assessed from environmental advertising, price, and environmentally friendly packaging had a significant effect on purchase intention (Ansar, 2013). Based on the results of these studies, the hypothesis is:

H1: Green Perceived Value has a significant effect on Purchase Intention.

\section{Image of Product towards Purchase Intention}

Previous research has shown that the product image had a significant effect on purchase intention (Ko et al., 2013). In the retail industry environment, it is the product's image that significantly affects purchase intention (Haery, Dehaghi, \& Yazdani, 2013). According to Jacob et al. (2018) and Rorong, Mandey, and Soepeno (2018), product image has a significant effect on purchase intention among millennials. Accordingly, the researchers further assume that the product image influences consumer purchase intentions. Based on these studies, the following hypothesis is proposed:

H2: Image of Product has a significant effect on Purchase Intention.

\section{Company Reputation towards Purchase Intention}

In environmentally friendly company performance, company reputation significantly affects purchase intention (Nyilasy, Gangadharbatla, \& Paladino, 2014). In line with this, Suki and Suki (2019) and Jung and Seock (2016) stated that the company reputation significantly influences the purchase intention. The researchers then speculate that the company reputation affects consumer purchase intention. As a result, the researchers put forward the following hypothesis:

H3: Company Reputation has a significant effect on Purchase Intention.

\section{Green Perceived Value towards Image of Product}

Previous research discovered that green perceived value had a considerable influence on product image (Ko et al., 2013). In the retail industry environment, it is the 
green perceived value that remarkably affects the product image (Haery et al., 2013). Other studies also revealed that green perceived value significantly affected product image as assessed from the information on the product label (D 'Souza, Taghian, \& Lamb, 2006). Based on the results of these studies, the researchers propound the following hypothesis:

H4: Green Perceived Value has a significant effect on the Image of the Product.

\section{Green Perceived Value towards Company Reputation}

Research conducted by Ko et al. (2013) found that green perceived value greatly influenced a company's reputation. Moreover, the green perceived value also affects the company's reputation in the performance of environmentally friendly companies (Nyilasy et al., 2014). Other research pointed out that green perceived value affected company performance shaping the company reputation, which is identified from its strategic resources and corporate environmental governance (Tang, Lai, \& Cheng, 2012). Based on the results of the studies, a hypothesis can be formulated as follows:

H5: Green Perceived Value has a significant effect on Company Reputation.

\section{Image of Product as a mediator of Green Perceived Value towards Purchase Intention}

The relationship between green perceived value and purchase intention directly affects the independent variable on the dependent variable. The relationship between these two variables is expected to meliorate if it has support from the connecting variable, namely the product image. Several studies indicated that green perceived value significantly affected purchase intention through product image mediation (Ko et al., 2013). In fact, in the retail industry environment, the green perceived value substantially affects purchase intention through product image mediation (Haery et al., 21013). Other research revealed that Green Perceived Value influenced the image of environmentally friendly products, thus increasing consumer desire to buy the products (de Medeiros, Ribeiro, \& Cortimiglia, 2016). A good product image will build a positive image in the minds of consumers so that the effect of green perceived value on the product has a significant effect on consumer purchase intention (K. A. A. Dewi \& Aksari, 2017). Accordingly, the following hypothesis is formulated:

H6: Image of Product can be a significant mediator on the effect of Green Perceived Value towards Purchase Intention.

\section{Company Reputation as a mediator of Green Perceived Value towards Purchase Intention}

The relation between green perceived value and purchase intention is a direct outcome of the independent variable on the dependent variable. The correlation between the two variables is expected to improve if supported by the connecting variable, namely company reputation. Several studies discovered that green perceived value had a critical effect on purchase intention through company reputation mediation (Ko et al., 2013). Other research showed that green perceived value influenced company performance establishing the company reputation. Thus, it affected consumers to prefer environmentally friendly products (Tang et al., 2012). The company reputation can affect the relationship between green perceived value and consumer purchase intention since green marketing activities have an impact on the good reputation of the company in the consumers' viewpoint (Saputra \& Ardani, 2017). Based on this, a hypothesis is proposed: H7: Company Reputation can be a significant mediator on the effect of Green Perceived Value towards Purchase Intention.

\section{RESEARCH METHODS}

This research aimed to develop a research model on the purchase intention of potential consumers. The method employed in this research was the ex-post facto method. 
Ex-post facto research is ideal for conducting research when it is impossible to manipulate the respondent's characteristics. The ex-post facto research intends to find causes that allow changes in behavior, symptoms, or phenomena caused by an event that has already occurred. Population, Sample, and Sampling Technique, the population in this research was the community in Malang City. The sample chosen was the community in Malang City who recognized the existence of beverage products with cardboard packaging and intended to buy the packaged beverage products. Samples of 300 people determined as respondents were selected by convenience.

Definition of Operational Variables

From the hypotheses set by the researchers, the complete operational variables will be demonstrated along with the indicators of each variable that have been adjusted to the needs of this research, as shown in table 1 .

Table 1.Indicators of Research Variables Source

\begin{tabular}{l} 
Variable \\
\hline Green Perceived Value \\
$(\mathbf{X})$ is the consumer's \\
assessment of the \\
benefits of an \\
environmentally friendly \\
product between what is \\
received and what the \\
company provides
\end{tabular}

Purchase Intention (Y) consumer's intention to make a purchase

Indicator

1. The product has an excellent value for consumers.

2. The product has the performance that consumers expect.

3. The product has more environmental awareness than other products.

4. The product has the advantage of being environmentally friendly.

5. The product has more environmental benefits than other products.

1. The desire to buy in the future

2. Certainty for choosing a product

3. Certainty for buying the product

4. Trust in the product

$\begin{array}{ll}\text { Code } & \text { Source } \\ \text { GPV1 } & \begin{array}{l}\text { (Chen \& Chang, } \\ \text { 2012), (Patterson } \\ \text { \& Spreng, 1997) }\end{array} \\ \text { GPV2 } & \\ \text { GPV4 } & \\ \text { GPV5 } & \\ & \\ \text { PI 1 } & \\ \text { PI 2 } & \\ \text { PI 3 } & \\ \text { PI 4 } & \text { (Keh \& Xie, } \\ & \text { Chen \& Chang, } \\ & \text { 2012) (Orth, } \\ \text { Koenig, \& }\end{array}$

CR 1

CR 2

CR 3

CR 4

CR 5

CR 6
( Keh \& Xie, $\underline{2009})$

(Ko et al., 2013)

(Pratiwi, 2013) establishes in maintaining a good name,thus giving consumers an environmentally friendly perception.

\section{Data Collection and Measurement}

Data in this research were collected through a survey using an online distributed questionnaire created via Google Form. The questionnaire link was then distributed to potential respondents to be objectively assessed. The respondents' answers were assessed as follows; strongly agree with a score of 5, agree with a score of 4 , doubt/neutral was given a score of 3 , disagree with a score of 2 , and strongly disagree was given a score of 
1. The first instruments employed were the validity and reliability tests. The validity test was carried out by confirmatory analysis, while the reliability test used Cronbach Alpha. The result of the instrument test using a sample of 40 respondents demonstrated adequate validity values ranging from 0.638 to 0.909 . Meanwhile, the reliability values were 0.787 to 0.840 , indicating that all variable measurement items were valid and reliable.

Data Analysis and Evaluation of the Goodness Model

The data analysis used in this research was SEM-AMOS analysis. Data analysis is intended to examine the effect of several dependent (exogenous) variables on the independent (endogenous) variables and the mediating variables. Testing was carried out using the Structural Equation Modeling method by employing AMOS software (Waluyo, 2011; Widayat, 2016). In this step, the model's determination is evaluated by reviewing various goodness of fit criteria. Evaluation of the accuracy of the model estimated by AMOS (Hair, Anderson, Babin, \& Black, 2010; Widayat, 2018b) is contained in the following table:

Tabel 2. Goodness of Fit Model

\begin{tabular}{lc}
\hline \multicolumn{1}{c}{ Chi-Square } & Critical Value \\
\hline ABSOLUTE & \\
Chi-Square $\left(\mathrm{X}^{2}\right)$ & Insignificant \\
Significant Probability & $>0.05$ \\
GFI & $>0.90$ \\
RMSEA & $<0.08$ \\
INCREMENTAL & \\
NFI & $>0.90$ \\
TLI & $>0.90$ \\
CFI & $>0.90$ \\
RFI & $>0.90$ \\
PARSIMONIOUS & \\
CMIN/DF & $<3.00$ \\
\hline
\end{tabular}

\section{RESEARCH RESULTS AND DISCUSSION}

Before discussing the causality model for the determinant of the repurchase intention variable, several demographic variables related to respondents, including gender, age, and latest education, are revealed in this paper. These are presented in Table 4 to Table 6 . Table 4 shows more female respondents since women are more consumptive than men, and women are more concerned about the environment for the impact of the goods they consume. Meanwhile, Table 5 displays that there are more respondents aged 15-25 years than respondents with other age levels. This indicates that this age group is more likely to purchase environmentally friendly products than other age groups. Concerning the last education, it is illustrated in Table 6 that there are more respondents with the latest education of Bachelor/Master/Doctoral degree than respondents with other last education levels. This denotes that the respondents with these latest education levels have the awareness and knowledge to buy environmentally friendly cardboard packaging beverages.

Table 3. Characteristics of Respondents based on gender

\begin{tabular}{ccc}
\hline Gender & Respondent & Percentage \\
\hline Male & 116 & $38.7 \%$ \\
Female & 184 & $61.3 \%$ \\
Total & $\mathbf{3 0 0}$ People & $100 \%$ \\
\hline
\end{tabular}


Table 4. Characteristics of Respondents based on Age

\begin{tabular}{ccc}
\hline Age & Respondent & Percentage \\
\hline $15-25$ Years Old & 186 & $62 \%$ \\
$26-35$ Years Old & 86 & $28.7 \%$ \\
$36-45$ Years Old & 21 & $7 \%$ \\
$46-60$ Years Old & 7 & $2.3 \%$ \\
Over 60 Years Old & 0 & 0 \\
Total & $\mathbf{3 0 0}$ People & $100 \%$ \\
\hline
\end{tabular}

Table 5. Characteristics of Respondents based on Last Education

\begin{tabular}{|c|c|c|}
\hline Last Education & Respondent & Percentage \\
\hline Elementary School & 0 & 0 \\
\hline Junior High School & 7 & $2.3 \%$ \\
\hline Senior High School & 108 & $36 \%$ \\
\hline Diploma1/ Diploma 2/ Diploma 3 & 44 & $14.7 \%$ \\
\hline Bachelor/Master/Doctoral degree & 141 & $47 \%$ \\
\hline Total & 300 People & \\
\hline
\end{tabular}

Evaluation of the Causality Model among Variables

After the confirmatory factor analysis testing was conducted, it was found that several indicators must be removed because they did not meet the requirements in modeling. Also, in this modeling, several tests are carried out as a requisite, including normality and the presence of outliers. The data normality test was performed using the critical ratio skewness value criteria of 2.58 at a significance of $5 \%$. The data are considered to be normally distributed if the critical ratio skewness and kurtosis value are below the absolute price of 2.58. In general, it can be stated that the research data have met the normal assumptions since the values of c.r skew and c.r kurtosis are in the range of -2.5 to 2.5 . The result of the multivariate normality test was 0.790 , indicating that the research data meet the modeling requirements.

Model Evaluation

The results of the calculation producing goodness of fit index showed that the requirements had fulfilled (fit), and the results could be used as the basis for this research. Furthermore, the dimensions that formed the variables, both independent and dependent variables, were precise so that the research model could be accepted, as shown in Table 6 below:

Table 6. Goodness of Fit Index

\begin{tabular}{lccc}
\hline Chi-Square & Critical Value & $\begin{array}{c}\text { Final } \\
\text { score }\end{array}$ & Conclusion \\
\hline ABSOLUTE & Insignificant & 155.065 & \\
$\begin{array}{l}\text { Chi-Square }\left(\mathrm{X}^{2}\right) \\
\quad \text { Significant }\end{array}$ & $>0.05$ & 0.000 & \\
$\begin{array}{l}\text { Probability } \\
\text { GFI }\end{array}$ & $>0.90$ & 0.915 & Good Fit \\
RMSEA & $<0.08$ & 0.081 & Good Fit \\
INCREMENTAL & $>0.90$ & & \\
NFI & $>0.90$ & 0.905 & Good Fit \\
TLI & $>0.90$ & 0.921 & Good Fit \\
CFI & $>0.90$ & 0.939 & Good Fit \\
RFI & & 0.877 & Good Fit \\
PARSIMONIOUS & $<.00$ & & \\
CMIN/DF & & 2.584 & Good Fit \\
HOELTER & & & \\
Hoelter 0.05 & & 125 & \\
Hoelter 0.01 & & $\mathbf{1 4 0}$ & \\
\hline
\end{tabular}

Reliability Evaluation

This evaluation is utilized to determine the achievement of reliability values such as the value of CR (Construct Reliability) > 0.70 and the value of VE (Variance 
Extracted) $>0.50$. The modeling results in Table 11 display that the $\mathrm{CR}$ value is above 0.70 for each variable, and the VE value is above 0.50 for each variable. As a result, it can be concluded that all variables are valid and reliable. As shown in Table 7.

Table 7. Reliability Evaluation

\begin{tabular}{lccc}
\hline \multicolumn{1}{c}{ Variable } & CR & VE & Conclusion \\
\hline Green Perceived Value & 0.84 & 0.76 & Valid and Reliable \\
Image of Product & 0.70 & 0.51 & Valid and Reliable \\
Company Reputation & 0.82 & 0.73 & Valid and Reliable \\
Purchase Intention & 0.88 & 0.83 & Valid and Reliable \\
\hline
\end{tabular}

Final Stage Model

The final modeling results indicated that the loading factor value was above 0.60 , which was in accordance with what has been determined. The IP1 indicator had a loading factor of 0.59 , yet it was still maintained. This states that all indicators of each variable are considered valid for research. The test results were also analyzed by considering the Modification Indices, which produced several correlations among indicators aiming to generate a better model, as shown in Figure 4.

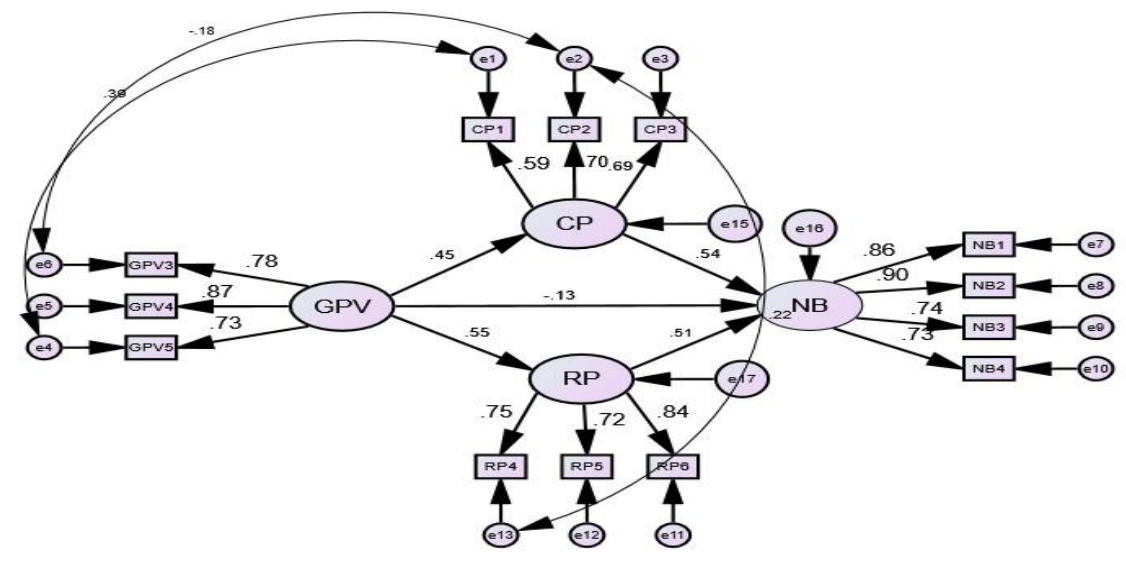

Figure 2. The Model of Determinant Connection of Final Repurchase Intention

\section{Description}

GPV: Green Perceived Value

CP: Image of Product

RP: Company Reputation

NB: Purchase Intention

Direct Influence among Variables

In Table 12, regarding the regression weight, it can be explained that the effect of green perceived value on purchase intention is not significant since the probability value is above 0.05 . Meanwhile, the impact of green perceived value on the product image and company reputation is significant. The influence of the mediating variables, namely product image and company reputation, also shows a significant effect on purchase intention. 
Table 8. Regression Weights

\begin{tabular}{|c|c|c|c|c|c|}
\hline & Estimate & SE. & CR. & $\mathrm{P}$ & Label \\
\hline IP <--- GPV & .428 & .084 & 5.090 & $* * *$ & Significant \\
\hline CR <--- GPV & .696 & .097 & 7.151 & $* * *$ & Significant \\
\hline PI <--- IP & .686 & .117 & 5.841 & $* * *$ & Significant \\
\hline PI <--- CR & .492 & .078 & 6.288 & $* * *$ & Significant \\
\hline PI <--- GPV & -.156 & .104 & $\begin{array}{c}- \\
1.502\end{array}$ & .133 & Not Significant \\
\hline
\end{tabular}

The coefficient of the effect of green perceived value on purchase intention is 0.128 , and the probability is 0.133 , which is greater than 0.05 . This indicates that green perceived value has no significant effect on purchase intention. The result is in line with Chang's (2015) research, stating that green perceived value has no significant impact on purchase intention. This condition occurs due to greenwashing, causing people to lose trust in environmentally friendly products. Accordingly, consumers sense distrust when buying environmentally friendly cardboard packaging beverage products.

Meanwhile, the coefficient of the product image's effect on purchase intention is 0.540 , and the probability is $0.000(\mathrm{p}<0.05)$. These numbers indicate that the image of the product affects the purchase intention significantly. This means that the better the image of the cardboard packaging beverage products received by the consumers, the higher the consumers' purchase intention towards the products. This finding is following the research of Ko et al. (2013), Haery et al. (2013), Jacob et al. (2018), and Rorong et al. (2018), claiming that the product image has a significant effect on purchase intention. Moreover, the effect of company reputation on purchase intention is 0.509 , and the probability is $0.000(\mathrm{p}<0.05)$, meaning that the company reputation has a significant influence on purchase intention; that is, the better the company reputation seen by consumers, the higher consumer's purchase intention of cardboard packaging beverage products. This result is similar to the research of Ko et al. (2013), Nyilasy et al. (2014), Suki and Suki (2019), and Jung and Seock (2016) stating that company reputation has a significant effect on purchase intention.

Furthermore, the effect of green perceived value on the product image is indicated by a beta coefficient of 0.446 and a probability of $0.000(\mathrm{p}<0.05)$. This denotes that green perceived value has a remarkable influence on the product image, meaning that the more environmentally friendly benefits of cardboard packaging are, the image of cardboard packaging beverages will be more excellent for consumers. This result is related to the research of Ko et al. (2013), Heryery et al. (2013), and D'Souza et al. (2006), arguing that green perceived value has a significant effect on the product image. Meanwhile, the effect of green perceived value on company reputation is also significant with a beta coefficient of 0.552 and a probability of $0.000(\mathrm{p}<0.05)$, which means that the more beneficial values in cardboard packaging beverages, the reputation of a company committed to environmental sustainability will be more magnificent for consumers. This discovery is consistent with the research of Ko et al. (2013), Nyilasy et al. (2014), and Tang et al. (2012), which stated that green perceived value significantly affects the company reputation.

\section{The Role of Moderation}

The Sobel test is employed to test the role of the mediating variable between the independent and dependent variables, using the online Sobel calculator. The role of the product image mediation variable (IP) on the effect of green perceived value (GPV) towards purchase intention (PI) can be determined by conducting a Sobel test. The impact of green perceived value on product image had an estimated value of 0.428 and a standard 
error value of 0.084 . Meanwhile, the effect of the product image on purchase intention had an estimated value of 0.686 and a standard error value of 0.118 . The p-value on the online Sobel test was $0.00012009<0.05$.

Consequently, the indirect effect of the Green Perceived Value variable on Purchase Intention through Image of Product is proven significant. In other words, the Image of Product as a mediator between Green Perceived Value and Purchase Intention plays a role. From the results of the Sobel test calculation, a p-value of $0.00012009<0.05$ was obtained, meaning that there is an indirect effect of the Green Perceived Value variable on Purchase Intention through Image of Product. In short, the Image of Product as a mediator between Green Perceived Value and Purchase Intention plays an important role. This result is associated with the research of Ko et al. (2013), Haery et al. (2013), de Medeiros et al. (2016), as well as K. A. A. Dewi and Aksari (2017) claiming that product image can be a significant mediator on the effect of green perceived value towards purchase intention.

Moreover, the role of the company reputation mediating variable on the effect of green perceived value towards purchase intention can be determined by conducting a Sobel test. The impact of green perceived value on company reputation had an estimated value of 0.696 and a standard error value of 0.097 , while the effect of the product image on purchase intention had an estimated value of 0.492 and a standard error value of 0.078 . The p-value in the Sobel test was $0.00000216<0.05$. Accordingly, it can be said that the indirect effect of the Green Perceived Value variable on Purchase Intention through Image of Product is significant. To put it another way, the Image of Product as a mediator between Green Perceived Value and Purchase Intention plays a crucial role. The Sobel value on the company reputation variable obtained a p-value of $0.00000216<0.05$. This means that the Green Perceived Value variable on Purchase Intention through Company Reputation is significant. In other words, the company reputation plays a role as a mediator between Green Perceived Value and Purchase Intention. This result is in line with the research of Ko et al. (2013), Tang et al. (2012), and Saputra and Ardani (2017), who argued that company reputation could be a significant mediator on the effect of green perceived value towards purchase intention.

\section{CONCLUSIONS AND RECOMMENDATIONS}

Based on the results of this research, several conclusions can be drawn regarding the relationship among variables. Firstly, Green Perceived Value has no significant effect on Purchase Intention. Secondly, Company Reputation significantly affects Purchase Intention. This means that the reputation established by the cardboard packaging beverage company can influence consumers in Malang to buy cardboard packaging beverages. Thirdly, Green Perceived Value has a remarkable effect on the Image of a Product, meaning that environmentally friendly values in cardboard packaging beverages will build a good image on the product itself. Lastly, Green Perceived Value influences Company Reputation greatly, that is, environmentally friendly values in cardboard packaging beverages will form a good reputation for companies committed to environmental sustainability. Moreover, Image of Product and Company Reputation can be significant mediators on the effect of Green Perceived Value towards Purchase Intention.

Based on the previous research and conclusions, several suggestions can be considered by practitioners and academics; namely companies intended to implement environmentally friendly concepts must establish a company reputation and product image in advance. Further, this research needs to be explored more by further researchers such as increasing the number of samples, and the data that have been collected through a questionnaire can be supplemented with data collection from interviews aiming to dig 
deeper into the things behind the reasons why consumers intend to purchase cardboard packaging beverage products.

\section{REFERENCES}

Ajzen, I. (1985). From intentions to actions: A theory of planned behavior. In Action control (pp. 11-39): Springer.

Alma, B. (2007). Manajemen pemasaran dan pemasaran jasa. Bandung: Alfabeta.

Ansar, N. (2013). Impact of green marketing on consumer purchase intention. Mediterranean Journal of Social Sciences, 4(11), 650.

Assael, H. (1998). Consumer behavior and marketing action, 1998. South-Western College Publishing, US, 23-24.

Chang, S.-H. (, 2015). The Influence of Green Viral Communications on Green Purchase Intentions: The Mediating Role of Consumers' Susceptibility to Interpersonal Influences. Sustainability, 7(5), 4829-4849. DOI:10.3390/su7054829

Chen, Y.-S., \& Chang, C.-H. (2012). Enhance green purchase intentions: The roles of green perceived value, green perceived risk, and green trust. Management Decision, 50(3), 502-520.

D'Souza, C., Taghian, M., \& Lamb, P. (2006). An empirical study on the influence of environmental labels on consumers. Corporate communications: an international journal, 11(2), 162-173.

De Medeiros, J. F., Ribeiro, J. L. D., \& Cortimiglia, M. N. (2016). Influence of perceived value on purchasing decisions of green products in Brazil. Journal of Cleaner Production, 110, 158-169. DOI:10.1016/j.jclepro.2015.07.100

Dewi, K. A. A., \& Aksari, N. M. A. (2017). Peran Brand Image dalam Memediasi Pengaruh Green Marketing terhadap Keputusan Pembelian (Studi Kasus Produk Oriflame di Kota Denpasar). E-Jurnal Manajemen Universitas Udayana, 6(11).

Dewi, S. A., \& Rastini, N. M. (2016). Peran Green Trust Memediasi Green Perceived Value Dan Green Perceived Risk Terhadap Green Repurchase Intention. EJurnal Manajemen, 5(12).

do Paço, A., \& Raposo, M. (2009). "Green" segmentation: an application to the Portuguese consumer market. Marketing Intelligence \& Planning, 27(3), 364379. DOI: $10.1108 / 02634500910955245$

Doszhanov, A., \& Ahmad, Z. A. (2015). Customers' intention to use green products: the impact of green brand dimensions and green perceived value. Paper presented at the SHS Web of Conferences.

Fonseca, J. C. G. (2015). The impact of green marketing practices on consumer buying decisions.

Haery, F. A., Dehaghi, M. R., \& Yazdani, A. (2013). Effect of Green Marketing on Consumer Purchase Intentions With Regard to the Company's Image as a Mediator in the Retail Setting Case study: The Customers of Naghshe-e Jahan Sugar Company. International Journal of Academic Research in Business and Social Sciences, 3(11), 442.

Hair, J. F., Anderson, R. E., Babin, B. J., \& Black, W. C. (2010). Multivariate data analysis: A global perspective (Vol. 7). In: Upper Saddle River, NJ: Pearson.

Jacob, A. A., Lapian, S. J., \& Mandagie, Y. (2018). Pengaruh Daya Tarik Iklan dan Citra Produk terhadap Keputusan Pembelian Produk Chitato Chips pada

Mahasiswa FEB UNSRAT Jurnal EMBA: Jurnal Riset Ekonomi, Manajemen, Bisnis dan Akuntansi, 6(2).

Jessie Chen-Yu, H., \& Kincade, D. H. (2001). Effects of product image at three stages 
of the consumer decision process for apparel products: Alternative evaluation, purchase, and post-purchase. Journal of Fashion Marketing and Management: An International Journal, 5(1), 29-43.

Jung, N. Y., \& Seock, Y.-K. (2016). The impact of corporate reputation on brand attitude and purchase intention. Fashion and Textiles, 3(1), 20.

Keh, H. T., \& Xie, Y. (2009). Corporate reputation and customer behavioral intentions: The roles of trust, identification, and commitment. Industrial Marketing Management, 38(7), 732-742. DOI:10.1016/j.indmarman.2008.02.005

Ko, E., Hwang, Y. K., \& Kim, E. Y. (2013). Green marketing functions in building the corporate image in the retail setting. Journal of Business Research, 66(10), 1709-1715.

Li, X. G., Wang, X., \& Cai, Y. J. (2011). Corporate-, product-, and user-image dimensions and purchase intentions. Journal of Computers, 6(9), 1875-1879.

Nyilasy, G., Gangadharbatla, H., \& Paladino, A. (2014). Perceived greenwashing: The interactive effects of green advertising and corporate environmental performance on consumer reactions. Journal of Business Ethics, 125(4), 693707.

Orth, U. R., Koenig, H. F., \& Firbasova, Z. (2007). Cross-national differences in consumer response to the framing of advertising messages: an exploratory comparison from Central Europe. European Journal of Marketing, 41(3/4), 327348.

Patterson, P. G., \& Spreng, R. A. (1997). Modeling the relationship between perceived value, satisfaction, and repurchase intentions in a business-to-business services context: an empirical examination. International Journal of Service Industry Management, 8(5), 414-434.

Pratiwi, H. D. (2013). Pengaruh reputasi perusahaan dan kualitas website terhadap tingkat kepercayaan konsumen dalam bertransaksi secara online (studi pada konsumen Ongisnadestore. com). Fakultas Psikologi Universitas Brawijaya: Malang.

Rashid, N. (2009). Awareness of eco-label in Malaysia's green marketing initiative. International Journal of Business and Management, 4(8), 132-141.

Rezvani, S., Dehkordi, G. J., Rahman, M. S., Fouladivanda, F., Habibi, M., \& Eghtebasi, S. (2012). A conceptual study on the country of origin effect on consumer purchase intention. Asian Social Science, 8(12), 205-215.

Rorong, I. L., Mandey, S., \& Soepeno, D. (2018). Pengaruh Citra Konsumen dan Citra Produk terhadap Keputusan Pembelian Produk Kosmetik VIVA (Studi Kasus Mahasiswa Fakultas Ekonomi dan Bisnis Jurusan Manajemen Angkatan 2014 UNSTRAT) Jurnal EMBA: Jurnal Riset Ekonomi, Manajemen, Bisnis dan Akuntansi, 6(4).

Salim, F. (2019). Pengaruh Kualitas Pelayanan dan Kepercayaan terhadap Kepuasan Pelanggan dan Dampaknya pada Reputasi Perusahaan (Studi Empiris pada Perusahaan Travel Umroh dan Haji di Jakarta Timur). EKOBISMAN-JURNAL EKONOMI BISNIS DAN MANAJEMEN, 4(2), 110-125.

Saputra, I. G. P. A., \& Ardani, I. G. A. K. S. (2017). Peran Brand Image Dalam Memediasi Pengaruh Green Marketing Terhadap Corporate Reputation. EJurnal Manajemen, 6(1), 87-115.

Singhal, A., \& Malik, G. (2018). The attitude and purchasing of female consumers towards green marketing related to the cosmetic industry. Journal of Science and Technology Policy Management. DOI:10.1108/jstpm-11-2017-0063

Suki, N. M., \& Suki, N. M. (2019). Correlations between green marketing awareness, corporate social responsibility, product image, corporate reputation, and 
consumer purchase intention. In Corporate Social Responsibility: Concepts, Methodologies, Tools, and Applications (pp. 143-154): IGI Global.

Tang, A. K., Lai, K. h., \& Cheng, T. (2012). Environmental governance of enterprises and their economic upshot through corporate reputation and customer satisfaction. Business Strategy and the environment, 21(6), 401-411.

Waluyo, M. (2011). Panduan dan aplikasi structural equation modelling. Jakarta: Indeks.

Wang, C. L., Li, D., Barnes, B. R., \& Ahn, J. (2012). Country image, product image, and consumer purchase intention: Evidence from an emerging economy. International Business Review, 21(6), 1041-1051.

Wang, X., \& Yang, Z. (2008). Does country-of-origin matter in the relationship between brand personality and purchase intention in emerging economies? Evidence from China's auto industry. International Marketing Review, 25(4), 458-474.

Widayat. (2016). Analisis Data Penelitian [Konsep Dan Aplikasi Pada Penelitian Kuantitatif] (Vol. 1). Malang: UMM Press.

Widayat. (2018a). E-Consumer Behavior: The Roles of Attitudes, Risk Perception on Shopping Intention-Behavior. Advances in Economics, Business, and Management Research, 57.

Widayat. (2018b). Statistika Multivariate, Pada Bidang Manajemen dan Bisnis. Malang: UMM Press.

Widyastuti, S., \& Santoso, B. (2016). Green Marketing: A Study of the Factors Influencing the Repurchase Decision for Javanony Herbal Products. ASEAN MARKETING JOURNAL, VII(2), 104-115. 